\title{
The International Academy of Cytology Yokohama System for Reporting Breast Fine Needle Aspiration Biopsy Cytopathology
}

\author{
Guest Editors \\ Andrew S. Field, Sydney, Australia \\ Wendy A. Raymond, Adelaide, Australia \\ Fernando C. Schmitt, Porto, Portugal
}

46 figures, 41 in color, and 25 tables, 2019 
S. Karger

Medical and Scientific Publishers

Basel $\cdot$ Freiburg $\cdot$ Hartford $\cdot$ Oxford

Bangkok $\cdot$ Dubai $\cdot$ Kuala Lumpur .

Melbourne $\cdot$ Mexico City .

Moscow $\cdot$ New Delhi $\cdot$ Paris .

Shanghai $\cdot$ Tokyo
Disclaimer

The statements, opinions and data contained in this publication are solely those of the individual authors and contributors and not of the publisher and the editor(s). The appearance of advertisements in the journal is not a warranty, endorsement, or approval of the products or services advertised or of their effectiveness, quality or safety. The publisher and the editor(s) disclaim responsibility for any injury to persons or property resulting from any ideas, methods, instructions or products referred to in the content or advertisements.

Drug Dosage

The authors and the publisher have exerted every effort to ensure that drug selection and dosage set forth in this text are in accord with current recommendations and practice at the time of publication. However, in view of ongoing research, changes in government regulations, and the constant flow of information relating to drug therapy and drug reactions, the reader is urged to check the package insert for each drug for any change in indications and dosage and for added warnings and precautions. This is particularly important when the recommended agent is a new and/or infrequently employed drug.
All rights reserved.

No part of this publication may be translated into other languages, reproduced or utilized in any form or by any means, electronic or mechanical, including photocopying, recording microcopying, or by any information storage and retrieval system, without permission in writing from the publisher or in the case of photocopying, direct payment of a specified fee to the Copyright Clearance Center (see "General Information")

(C) Copyright 2019 by S. Karger AG,

P.O. Box, CH-4009 Basel (Switzerland)

Printed on acid-free and non-aging paper (ISO 9706)

ISBN 978-3-318-06556-5

e-ISBN 978-3-318-06557-2

\section{KARGER}




\section{Contents}

Preface

255 The International Academy of Cytology Yokohama System for Reporting Breast Fine Needle Aspiration Biopsy Cytopathology

Field, A.S. (Sydney, NSW); Raymond, W.A. (Adelaide, SA); Schmitt, F.C. (Porto)

Review

257 The International Academy of Cytology Yokohama System for Reporting Breast Fine-Needle Aspiration Biopsy Cytopathology

Field, A.S. (Sydney, NSW); Raymond, W.A. (Adelaide, SA); Rickard, M.; Arnold, L. (Sydney, NSW); Brachtel, E.F. (Boston, MA); Chaiwun, B. (Chiang Mai); Chen, L. (Beijing); Di Bonito, L. (Trieste); Kurtycz, D.F.I. (Madison, WI); Lee, A.H.S.

(Nottingham); Lim, E. (Sydney, NSW); Ljung, B.-M. (San Francisco, CA); Michelow, P. (Johannesburg); Osamura, R.Y. (Kawasaki/Tokyo); Pinamonti, M. (Trieste); Sauer, T. (Oslo); Segara, D. (Sydney, NSW); Tse, G. (Sha Tin); Vielh, P. (Dudelange); Chong, P.Y. (Singapore); Schmitt, F. (Porto)

Research Articles

274 Breast Fine Needle Aspiration Biopsy Cytology Using the Newly Proposed IAC Yokohama System for Reporting Breast Cytopathology: The Experience of a Single Institution

Montezuma, D. (Porto); Malheiros, D. (São Paulo/Porto); Schmitt, F.C. (Porto)

280 The International Academy of Cytology Yokohama System for Reporting Breast Fine Needle Aspiration Biopsy Cytopathology: A Single Institutional Retrospective Study of the Application of the System Categories and the Impact of Rapid Onsite Evaluation

Wong, S.; Rickard, M.; Earls, P.; Arnold, L.; Bako, B.; Field, A.S. (Sydney, NSW)

Systematic Review

292 International Academy of Cytology Yokohama System for Reporting Breast Fine-Needle Aspiration Biopsy Cytopathology: A Review of Predictive Values and Risks of Malignancy

Hoda, R.S.; Brachtel, E.F. (Boston, MA) 
302 Ancillary Tests in Breast Cytology: A Practical Guide Beca, F. (Stanford, CA); Schmitt, F.C. (Porto)

Systematic Reviews

314 Fine-Needle Aspiration Biopsy Management of the Axilla in Primary Breast Carcinoma

Gibbons, C.E.; Quinn, C.M.; Gibbons, D. (Dublin)

319 Diagnostic Value of Fine-Needle Aspiration in Male Breast Lesions Hoda, R.S.; Arpin III, R.N.; Gottumukkala, R.V.; Hughes, K.S.; Ly, A.; Brachtel, E.F. (Boston, MA)

Reviews

328 Spindle Cell Lesions of the Breast on Fine-Needle Aspiration Biopsy: A Miscellany of Masses

Michelow, P. (Johannesburg); Field, A.S. (Sydney, NSW)

340 Histopathology and Cytopathology of Neuroendocrine Tumors and Carcinomas of the Breast: A Review

Osamura, R.Y. (Tokyo/Kawasaki); Matsui, N. (Kawasaki); Okubo, M. (Odawara); Chen, L. (Beijing); Field, A.S. (Sydney, NSW)

347 Author Index / Subject Index 